\title{
Has the COVID-19 pandemic manoeuvred policing in England and Wales towards a single national police organisation?
}

\author{
Karen Duckworth ${ }^{1}$
}

\begin{abstract}
In 2005, Her Majesty's Inspector of Constabularies, Sir Denis O'Connor, reported that structural change to the existing system of 43 forces in England and Wales was necessary, not just desirable (HMIC, 2005). He stated, "Re-configuring for better protection of, and connection with, the public, needs to be seen as part of a package of police reform for this century" (HMIC, 2005, p. 12). He was referring to the merging of smaller forces to make them "fit for purpose". In 2006, following the recommendations of the report, Home Secretary Charles Clarke took steps to begin a process of merging forces to drive efficiency and effectiveness in protective security. This strategic approach would have seen the number of forces reduced from 43 to 17 , but it encountered significant opposition from many of the existing Police Authorities, sufficient to stop it happening (BBC, 2006). In 2011, the Police Reform and Social Responsibility Act 2011 replaced existing Police Authorities with the current system of elected Police and Crime Commissioners (PCC), which enabled leadership, local priority setting and operational management of police, as well as new partnerships within many force areas. It also led to Home Office direction being largely limited to the Strategic Policing Requirement (SPR). As the 43-force structure continues, a collaborative approach is ever more necessary, and efforts have been focused on sharing specialist capabilities across forces (Regional Organised Crime Units being one such example). But is this sufficient for policing to keep apace of the changes threatening the safety and security of the public? The COVID-19 pandemic has shone a light on the operational effectiveness of the 43-force structure. This paper will examine the challenge to a system, which the House of Commons Home Affairs Select Committee (HASC) called "broken" in 2018 (HASC, 2018), through the lens of the COVID-19 pandemic, and discuss whether the public health crisis has accelerated the drive towards further policing reforms and even a national police organisation. The question will be considered within the context of national coordination arising from the pandemic, the impact on police legitimacy and lessons learnt from the unified policing models introduced in Scotland and the Netherlands in 2013.
\end{abstract}

Keywords: policing, pandemic, national coordination, reform

\section{Introduction}

An unprecedented situation that poses an urgent threat to public health and safety. It has put the police in the position of dealing with challenges they have never faced before, which they are having to navigate with sensitivity and diligence.

(Martin Hewitt QPM, 2020)

When National Police Chiefs' Council Chair, Martin Hewitt QPM, addressed London Policing College and University of West London's 2nd International Police Education Conference (2IPEC) on 8th December 2020, this was the frame in which he chose to outline the policing 
Vol. 8, No. 1, 114-130.

response. The United Kingdom (UK) had suffered 1.65 million COVID-19 infections and 60,ooo deaths (a figure that the Office for National Statistics (2021) had identified that had surpassed 100,000 by February 2021). There is no doubt that across many aspects of life, including policing, the impact of the COVID-19 pandemic has been devastating. In countries enduring lockdown during the first wave, police officers had to face not only the challenges of changes to roles and routines, but also the risk of infection, causing occupational stress and concerns about their own safety, as well as the safety of their family members. As many civilians started working from home, the police were asked to deal with suspects and victims who potentially had COVID19, often without adequate personal protective equipment (PPE). In several countries, the police were able to make the best use of technology to track the virus spread, as well as public compliance with public health restrictions. Emerging technology and innovation have had an impact on the police response around the world. In England and Wales, it has enabled a nationally coordinated approach to many aspects of policing, which had been found wanting due to the current policing structure in England and Wales. In his 2019 "State of Policing" report, Sir Tom Winsor is clear that the current structure of 43 forces has been overtaken by the demands and challenges of modern policing (HMICFRS, 2019). In England and Wales, we have moved to the Police Education Qualification Framework (PEQF) pathway for recruits after what the HASC described as "the alarming lack of consistency in professional standards and recruitment between different forces" (2016, cited in HASC, 2018, p. 64); we have a professional body overseeing national policing standards, values, and ethics in the shape of the relatively new College of Policing (established in 2013). As will be detailed, a new and innovative approach to police procurement has been launched, yet there are still barriers. Winsor is clear that policing reforms over the years have not been stringent enough and more is needed, much more. As a society, we will not be the same when we emerge from the pandemic. So many aspects of our lives will have changed, many for the better, and the same can be said for policing in England and Wales. At the December conference, DAC Matt Twist (2020) (Metropolitan Police Service Gold - Pandemic Response) made a key point: that it has been necessary for police leaders to ensure that the health crisis did not also become a crisis of policing, crime, and security. Underlining his and Winsor's earlier point, crime data during the period has illustrated potential changes in crime patterns and criminal modus operandi (Office for National Statistics, 2020). Senior Crime Prevention Advisor to the Swedish National Police, Supt May-Britt Ronnebro (2020), told the conference that in some countries the operation of the drugs markets changed over to online business, while in others the addicted had to turn to hospitals or NGOs for medical care, as no drugs were to be found on the street. Indeed, in Europe, Interpol highlight the practice of drug dealers using food delivery processes to support a home-delivery style drugs operation (Reuters, 2020). In a similar way within policing, the necessity to adapt in order to maintain delivery of service, in spite of the crisis, has led to innovation and new thinking that has taken advantage of new information technology (IT) or re-modelled existing operational functions to meet new demands and challenges. There have been some stand-out pieces of work that have demonstrated the versatility of the police family and put policing in a stronger position moving forward. For example, the use of drones to drop crime prevention information to harder to reach communities in the Republic of Ireland (Walsh, 2020). Also, the use of the National Demand Dashboard (NDD) by the New Zealand Police to place the very latest crime and COVID-19 data at the fingertips of decision-makers on an hourly basis during the pandemic. Simon Williams (Acting Director of New Zealand's Evidence Based Policing Centre) (2020) explained how the NDD, which is used mainly to monitor both actual and projected service demand across a number of policing responsibilities, such as disorder, family harm, mental health, road policing, and theft-related crime, was adapted to include COVID-19 related demand. This enabled police leaders to formulate a national response in terms of operational decision-making and resource deployment. 


\section{Police legitimacy}

Hewitt (2020) spoke about the clear national approach taken by police from the outset of the pandemic; to work with the public to ensure compliance with government guidance and support the drive to protect public health. Public trust in the integrity and honest endeavour of the police critically underpins legitimacy in policing. Neyroud (2021) noted the additional challenge to the current policing response, in so far as it is set against the backdrop of years of austerity where both policing and the police role have been "squeezed"; most notably in areas such as community policing and high visibility policing - the roles that the public can see and relate to. He compared the role of the police during the pandemic to that of walking a tightrope between the most extreme curtailing of public freedoms since World War 2 and eliciting public compliance with regulations. The manner in which this has been done has proved to be extremely challenging in the UK. However, in order to be able to police by consent, the police must manage the balance. Hewitt (2020) explained that the "4 E's" - Explain, Educate, Encourage, and Enforce - has been a strategy rooted in engagement. It is consistent with Nudge Theory (Thaler and Sunstein, 2008) and designed to persuade and encourage public compliance with the new laws though education and willing participation, with enforce being the last resort. This was an approach mirrored in other countries, as illustrated by Assistant Commissioner Richard Chambers (2020) who led the New Zealand Police pandemic response. He explained to delegates that his aim was to incorporate the Treaty of Waitangi principles of Participation, Partnership and Protection in the policing style and approach. One of the NZ police core values is commitment to the treaty. They made an early decision that their policing approach would be calm, confident, and compassionate, by implementing the graduated response model of the 4 E's. He was clear how important it was for senior leaders to support their vulnerable Maori communities, who are 8 times more at risk from COVID-19 (Chambers, 2020). In his conference presentation, Professor Ye (Zhejiang Police College, China) (2020) outlined how the Chinese Police had also recognised the value of community engagement and working with the community in order to identify risks (of COVID-19 or other major incidents looking forward). DAC Matt Twist stated that his strategy was based on emerging from the pandemic with the same or greater level of community engagement with the MPS than was evident when he started. When placed in the context of consensual policing, and the Peelian Principles (Home Office, 2012), it is interesting to hear that the importance of community engagement has been at the forefront of policing approaches across the world, even in China (albeit it in their own way), and, in China's case, despite some media commentary to the contrary, as reported by Shaw and Zhang's research (2020).

\section{National police coordination}

\section{Operation Talla}

When considering the challenges and benefits of national coordination in order to achieve a national policing approach, it is helpful to understand the roots of the tripartite system of police governance in England and Wales. Reiner (2000) suggests the Police Act 1964 was the turning point for unifying the fragmented nature of policing systems at the time and clarifying the relative powers of the Local Authority, National Government, and Chief Constables in framing and implementing police policy. The Act divided responsibility for policing policy between Local Police Authorities, the Home Office, and Chief Constables (excluding London). The Police and Magistrates Court Act 1994 made further adjustments to the tripartite system in terms of police accountability by introducing a framework for national planning and performance indicators. Not least, Police Authorities became independent from the local 
Vol. 8, No. 1, 114-130.

government structure. Through the Crime and Disorder Act 1998, and then the Police Reform Act 2002, additional requirements were placed on Police Authorities to produce 4-year plans consistent with the Government's National Policing Plan. Furthermore, it gave the Home Secretary powers to ensure good practice across the country through statutory codes of practice. Interestingly, it was now incumbent on a force to take remedial action if Her Majesty's Inspectorate of Constabulary deemed them inefficient or ineffective. The Police and Justice Act 2006 made amendments to the composition of Police Authorities to enhance their democratic legitimacy, for example, bringing independent community figures on board. However, the significant change was the Police Reform and Social Responsibility Act 2011, which replaced the Police Authority model with elected Police and Crime Commissioners (PCC) whose role was to improve police accountability. This is the model that remains today for managing performance and accountability for the 43 forces in England and Wales, but was this the missed opportunity to move to a national police service? In his 2005 report, "Closing the Gap", Sir Denis O'Connor QPM observes the following in regard to the national assessment carried out by police services above BCU level.

The findings are stark - very few forces assessed fully meet the required standard. It is also apparent that size matters: larger forces are likely to have much greater capability and resilience whilst smaller forces, in many cases, find it hard to provide the services to an acceptable standard. That said, being bigger is not enough to guarantee strong protective services. The environment (situation) also matters. For example, the presence of cities, ports, or events (i.e., repeated exposure to risks and challenges) also enhance the repertoire of protective services that forces offer the public. Able leadership can also be influential in allowing smaller forces to punch above their weight on these issues.

(HMIC, 2005, p. 2)

Protective services are categorised as Intelligence (what do we know about the issue?); prevention (what are we doing to stop this?); and enforcement/resolution (what ability do we have to intervene effectively?) (HMIC, 2005). The written evidence to the HASC (2018) by Crest Advisory outlines some concerns about the system of elected PCC in 2016:

1. PCC's are required to produce a 4-year Police and Crime Plan within a year of election, in line with Home Office Policing Priorities. Crest found during their research that a minority contained clear strategic priorities to guide resourcing decisions, and very few prioritised tackling specific crimes in line with the changing crime landscape (for example, only 6 prioritised cybercrime, 4 prioritised domestic violence etc.).

2. Only 50\% of the PCC's had set a performance strategy for which they could be held to account by the public (notably, PCC's are reliant on data from their respective forces, which they can then hold to account).

3. Limited consultation with the public in general terms was evident by the PCC's in collating public views about policing concerns.

Crest concluded that without a single national framework for determining policing priorities, PCC Police and Crime Plans would play a pivotal role in shaping the way police respond to changing crime demand, and the evidence in 2016 showed this to be weak.

So, does this strengthen the argument for national coordination? The 2020 Crest Research report notes that a success story of the pandemic's "first wave" has been the strengthening of the National Police Coordination Centre (NPoCC) (Crest, 2020). Formed in 2013, its role thus far has been limited (large-scale event planning and intelligence gathering where multiple forces were involved etc.). Yet the national approach to the pandemic (Operation Talla) proved NPoCC's significant value. For example, with government concern growing about officer absenteeism surpassing $20 \%$ (a trigger point for service delivery contingency plans), NPoCC collated national data to enable the government and NPoCC to have a clear national picture of staff availability on any given day. As the Crest Research 
report highlights, whilst this placed extra requirements on forces to share data, it also had the positive effect of improving reporting standards and local capability - something that would be positive for business-as-usual after the crisis. Hewitt (2020) observed that national coordination would be key in formulating a response to the ever-changing government guidance and restrictions. He accepted that this would not be easy, as forces faced very specific geographic challenges and interpretations. For example, those with national parks experienced different compliance challenges from visitors travelling for exercise than more urban forces, whose limited open spaces became over-utilised. The issue was certainly not aided by media coverage, which appeared to be seeking out inconsistencies (Day, 2020; Gant, 2021). However, the following case study shows how the national response to one aspect of policing has created a blueprint for the future.

\section{Case study}

\section{Operation Talla (PPE)}

The procurement and distribution of PPE to frontline officers in England/Wales was an area of huge concern in March 2020. In a briefing given on 16th September 2020, Supt Hannah Wheeler QPM (Project Lead) illustrated the context of the undertaking:

1. Demand for PPE globally was at unprecedented levels:

- Normal supply chains were emptied.

- Governments were introducing embargoes and "claim jumping" available stock.

- Prices increased by a factor of 5 times.

- Inexperienced and/or unscrupulous suppliers entered the market, leading to fake and defective PPE and certification and poor-quality control.

- Forces were competing with other organisations (NHS, social care etc.) for supply.

2. COVID-19 was not well understood and so guidance was constantly changing.

3. Outbreak in the USA was some 6 weeks behind the UK - this was going to make demand on PPE much more challenging.

This meant that forces were working independently and managing to secure some stock, but often in limited quantity and uncertain quality from a different part of the country. The main concern was that there was insufficient stock within the supply chain to meet the sustained requirements of the pandemic. In addition, there was no National Police Chiefs Council (NPCC) portfolio lead for PPE at the outset (Supt Wheeler took this role until Assistant Chief Constable Jason Masters was appointed). Supt Wheeler noted the immediate challenges she faced:

- Responding to an unprecedented public health pandemic.

- Assembling and managing a virtual team.

- No additional funding for PPE.

- Officers and staff loaned from across policing.

- No pre-existing PPE data.

- No guidance for use of new PPE.

- No agreed specification for PPE to bring consistency.

- HSE safety recall of masks at height of the pandemic.

- Certification.

- PPE in lockdown in Europe - China and the Far East the only option.

Indeed, such was the confusion and conflicting media coverage about PPE from overseas, that even when PPE from China was donated to the police, it was rejected for apparently failing to meet Health and Safety Executive (HSE) standards by some forces, whilst gratefully received by others. In addition, as understanding of the virus was developing and changing, so too was health guidance to the public and police officers. The Operation Talla 
Vol. 8, No. 1, 114-130.

team had to keep abreast of changing advice and make sure their communications and officer safety guidance was always current, without any sector-specific guidance available from Public Health England.

NPCC requested the establishment of a single central warehousing and distribution hub to be able to cope with the size of incoming/outgoing shipments of equipment, and Thames Valley Police (TVP) offered a venue, which was already servicing the regional Local Resilience Forum distribution. With assistance from the Royal Logistics Corps, TVP were able to set up a logistics operation, including infrastructure, and in effect, an "Amazon-style" operation was established. With procurement being undertaken on behalf of 43 forces, best prices and quality were initially achieved. A single, standard quality assurance certification process was implemented for all equipment, which provided reassurance across all 43 forces. A triage system was set up to monitor and manage orders, and all equipment picked, packed, and dispatched was audited through a stock management checklist and applied to the newly created cost recording and order scheduling/expediting system.

In an interview, Supt Hannah Wheeler QPM (H. Wheeler, personal communication, 29 January 2021) outlined what NPCC and NPoCC had learnt from wave one of the pandemic and what the success of the Operation Talla (PPE) blueprint meant for policing after the pandemic. The 'NPoCC Operation Talla (PPE)' national guidance document, was re-formulated based on a survey of forces, and began incorporating "frequently asked questions" from staff. The guidance document was split into two sections: a guide for senior managers and an interactive guide for staff. It was key that senior leaders made this front and central in their staff communications, something that had been inconsistent during wave one. Following an internal NPCC survey across the five forces with highest virus breakout rates, it was identified that the greatest cause of infection was internal transmission, i.e. contact in police buildings rather than contact with the public; a finding that Supt Wheeler noted was similarly reflected within the Fire Service. There are a number of considerations for why this was the case. One reason is that officers perceive greater risk from public contact and therefore are more stringent about PPE compliance when on patrol. However, once back in the station, they are more inclined to relax their guard, remove PPE (writing rooms, vending machines, offices), and touch surfaces. Another reason, Supt Wheeler noted was gained from her experience of linking in with frontline officers, was that it was hard to sustain focus on social distancing and infection prevention control during long and extended shifts when simultaneously trying to respond to the challenges of daily policing. Good ventilation has been seen to reduce transmission risk, however, there are areas in police stations where it is not possible to open windows (custody suites or control rooms, for example). It has also been established that $17-20 \%$ of transmission is via asymptomatic carriers (Pollock and Lancaster, 2020). This finding undermines the argument for whether frontline police officers should be given higher priority when considering vaccinations, given that the primary risk of infection is avoidable if more rigorous health/ hygiene measures are imposed within police buildings. It does, therefore, reaffirm the requirement for senior management to be rigorous about hygiene management within the police estate and remind staff about personal responsibility. An argument for vaccinating more vulnerable officers first could be made, but then, one could argue, perhaps they should not be on the frontline. However, traditional roles for officers unable to perform frontline duties have often been within stations, yet, as the findings show, this can actually pose a greater risk in some cases.

An interesting pattern emerged when NPCC considered absenteeism data and patterns across all 43 forces. A large northern urban force in a higher tier community recorded lower absenteeism (indeed, lower than pre-pandemic) than a rural southern force (3\% and $7.2 \%$ respectively in January 2021). A conclusion drawn from this by Supt Wheeler is that where one force was initially in a low tier, the sense of risk felt by community and officers 
was low and so PPE compliance was inconsistent amongst officers and less rigorous at senior leadership level. In the urban force, however, the greater risk of infection and higher tier status was well-publicised and, as a result, the force was a lot more stringent about officer safety, notably inside police buildings. For example, implementing infection prevention control measures like deploying COVID-19 marshals to patrol floors, ensuring social distancing and regular sanitising of workstations and communal areas.

Blue Light Commercial (BLC), a company funded by the Home Office until 31st March 2023 but owned by the PCCs, was launched in the summer. However, BLC found itself immediately at the heart of the Operation Talla (PPE) structure. It has taken over the hub's triage system of orders and distribution, acting as a buffer between the Department of Health and Social Care (DHSC) who were supplying PPE to order and the 43 forces ordering it on a weekly basis through the hub. Supt Wheeler noted that the original plan after wave one was to scale the hub down as a distribution centre and for DHSC to deliver directly to the forces. However, it was clear to her that the relationships and maturity of processes in both DHSC and the 43 forces were not strong enough, and the need to maintain stability was crucial as the country moved into a more severe phase of the pandemic. So, the hub remained. She observed that a major challenge of this piece of work has been the coordination of what are, effectively, 43 independent police "businesses", who do not all have the structure in place to up-scale to meet the commercial challenge of the pandemic. For example, overordering (inaccurate weekly requests to the tune of thousands of pieces of equipment due to a mistaken extra "o" on an order form) or a stores system geared up for business-as-usual in a smaller force, unable to cope with the scale of ordering and storage space necessary for the equipment. The hub has acted as an auditor of force PPE by collating orders and stocks through the ordering system, therefore knowing when orders submitted are incorrect by comparison of existing order data for that force. By default, this has provided a more streamlined provision of service, in spite of the many moving parts.

Looking ahead there are several successes arising from Operation Talla (PPE). Firstly, it has provided a blueprint for a national approach to procurement and distribution in a time of crisis, ensuring that the needs of 43 forces are met fairly and cost effectively. This can be overlayed onto any other crisis and any equipment involving multiple forces over a long period. For instance, Lateral Flow test kits for police are in scope for moving to the Operation Talla (PPE) remit. Secondly, one of the single biggest PPE problems for all public services initially, including the NHS, was the poor maintenance of stockpiles. One option under consideration is that future police PPE stockpile numbers will be agreed by forces and retained and rotated by suppliers. However, the risk is that the government can override contracts and divert stock from source to other public services. An alternative is a national police resource that is retained and rotated etc., but that would require funding contribution from the forces. Whichever option is taken, the enduring success will be that all police PPE stocks in the country are overseen by BLC as part of their business-as-usual delivery programme on the new National PPE Dashboard. By March 2022, BLC will also be in a position, when the provision of free PPE from DHSC ceases, to have negotiated on-going, commercially competitive supply contracts. The BLC model needs to be considered within the wider national police coordination discussion.

\section{Procurement}

In evidence to the Home Affairs Select Committee (HASC), in particular reference to police procurement of technology, Police Minister Nick Hurd referred to the "central challenge around the historic approach to procurement with insufficient understanding of what they were buying and insufficient collaboration" (HASC, 2018, p. 63). In an interview with Stuart Jose (Regional Commercial Director - BLC), he outlined the concept of BLC and its 
Vol. 8, No. 1, 114-130.

strengths and challenges (S. Jose, personal communication, 27 January 2021). There are four pillars to the BLC model:

1. Fleet and Aviation - all fleet and transport management/procurement (including NPAS)

2. People and Professional Services - including legal services, agency staff contingent labour, consultants, $\mathrm{OH}$ and wellness services, police pension provision administration and insurance etc.

3. Operational Services - all uniform, business-as-usual PPE, firearms, ammunition etc.

4. Property - construction (new custody centre, for example), facilities management etc. Whilst funded by the Home Office until March 2023, and owned by the 43 PCCs, its use by forces is not mandatory. There are occasions when forces require particular skills for operational reasons that are better identified and procured locally. However, it is clear that the strength of BLC lies in its commercial power in the marketplace when securing contracts on behalf of a number of/all forces. As PCC's take on responsibility for Fire and Rescue in the future, so BLC can take on linked procurement responsibilities. Indeed, as the Policing and Crime Act 2017 created a "duty to collaborate" amongst blue light services, this is a step in that direction and links in closely to the Local Resilience Forum network. The Emergency Services Collaborations Working Group (ESCWG) was established in 2014 to push forward that agenda. The Emergency Services Times (2017) reports that the ESCWG is "underpinned by the principle that change should be centrally supported but locally driven. Its vision is that collaboration should be sought in the interests of smarter strategic and operational working with other emergency services" (Emergency Service Times, 2017, para. 2). Medical emergency co-response schemes already embedded across the country are making a significant impact on demand management/rationalisation. An even bigger step is co-locating blue light services in the same hubs, and the ESCWG noted in a ministerial briefing document that shared asset/estate schemes were already well underway up and down the country (ESCWG, 2017). For example, Cheshire's "Blue Light Collaboration Programme" will see Cheshire Fire relocating to the police HQ, with the creation of a joint vehicle workshop and joint back-office departments, delivering functions for both organisations and identifying for further co-location opportunities across the county. Significant financial savings can be made, as well as an improvement in efficiency and effectiveness. In Wales, a plan supported by the Welsh Government and PCC to merge the control rooms of Mid, West and South Wales Fire and Rescue with South Wales Police into a single co-located facility is anticipated to achieve an annual saving of $£ 2$ million. In Gloucestershire, a single transport hub has been set up to service and repair all county ambulance, police, fire and rescue vehicles.

\section{The national policing vision}

The last decade has seen fast-paced change in policing governance and standardization, with the formation of the College of Policing in 2013 and the replacement of the Association of Chief Police Officers (ACPO) with NPCC. This was brought about in 2013 when the PCCs commissioned the Parker review to make recommendations for the development of a modernised and simplified national body. The Policing Vision 2025 (NPCC, 2016) sets out the strategy for policing up to 2025, and is set to shape decisions about how police forces use their resources to keep people safe. In the report, policing in 2025 will look like the following:

A) The link between communities and the police will continue to form the bedrock of British policing. Local policing will be tailored to society's complex and diverse needs - with the delivery of public protection being informed by community priorities and robust, evidence-based, demand analysis.

B) Our specialist capabilities will be better prepared to respond to existing and emerging crime types. Decisions on how capabilities are positioned, structured, and 
deployed will take into account the need to rapidly protect communities and the vulnerable, as well as provide value for money.

C) The police service will attract and retain a workforce of confident professionals able to operate with a high degree of autonomy and accountability, and will better reflect its communities.

D) Digital policing will make it easier for the public to make contact with the police wherever they are in the country, enable us to make better use of digital intelligence and evidence, and transfer all material in a digital format to the criminal justice system.

E) Policing will be agile and outward focused. Police forces and their partners will work together in a consistent manner to enable joined-up business delivery around policing support services and community safety.

Each one of the five pillars supports the move towards a single national police force structure. However, as highlighted to the HASC (2018) by Lynne Owens DCB CBE QPM (Director General of the National Crime Agency), there is a contrast in structure applied to Serious and Organised Crime response (funding and governance is localised) and Counter Terrorism (nationally coordinated by the National Counter-Terrorism Policing Headquarters (NCTPHQ)). She says:

The NCTPHQ devises policy and strategy, advises the Government on how counterterrorism budgets should be allocated to police forces in England and Wales, and provides corporate and support services to a network of counter-terrorism units (CTUs) and counter-terrorism intelligence units, which gather local intelligence. Five CTUs make up the National Counter-Terrorism Network, and together are accountable to the NPCC's Counter-Terrorism Coordination Committee.

(2018, cited in HASC, 2018, p. 75)

In evidence to the Committee, Dame Lynne Owens, Dame Cressida Dick DBE QPM (Commissioner of the Metropolitan Police Service), and Chief Constable Dame Sara Thornton DBE QPM stated that Counter Terrorism policing is the area where they felt most confident about the police service's ability to adapt and respond to new challenges (HASC, 2018). So, is it time to adopt a similar model to counter the serious and organised crimes outlined in the NPCC Vision 2015, which require a globally coordinated, not just national, response?

\section{Integrated technology}

The Crest review drew the conclusion that some of the changes seen during the pandemic were less due to innovation, but merely long overdue and given impetus of necessity by the pandemic (Crest Advisory, 2020). It could be said that the pandemic has been a leveller and has made policing confront some of the existing flaws in its systems. For example, the need to collate national data about PPE stocks and requirements has lifted the lid on problems with the way some forces manage their resources. Not only in terms of storage, but also in the sometimes "haphazard" data collection and supply. Bearing in mind that this was data being collated and shared to NPCC and the Home Secretary, and used to make critical decisions, this is very concerning. Stuart Jose (S. Jose, personal communication, 27 January 2021) highlights the single biggest barrier to change - Information Technology (IT). The enormous cost associated with creating an IT base that synchronises functionality across UK police forces is often held up as a barrier to change. However, what will be the cost of not doing it? The HASC (2018) finding, in respect of police service investment in and adoption of new IT, was "quite frankly, a complete and utter mess". However, the committee goes further still:

We believe that the biggest failing in this area is not the level of funding, but rather the complete lack of coordination and leadership on upgrading technology over very many years. This is badly letting down police officers, who are struggling to do their 
Vol. 8, No. 1, 114-130.

jobs effectively with out-of-date technology. It is astonishing that, in 2018, police forces are still struggling to get crucial real-time information from each other, and that officers are facing frustration and delays on a daily basis.

(HASC, 2018)

In the case of the Metropolitan Police (MPS), John Biggs makes the point in the London Assembly Report (2013) that the MPS has long since been wasting money on supporting old IT systems. In support of Biggs's point, Strom (2017) asserts that good IT will improve productivity, however, it is necessary to understand the technology that is available and what best suits the purpose for which it is intended. HMICFRS (2014) agree, noting that good use of technology can improve productivity, but up-to-date IT is critical for officers to undertake their roles in the best way possible. One of the most important considerations for progression of a national police organisation is shared IT platforms. The National Enabling Programme (NEP) provides a mechanism for this (National Enabling Programme, 2020). Unlike the current structure, where everything from command and control to crime investigation, call handling, or custody management is handled on different systems or with different operation procedures in different forces, introducing Productivity Services (based on the Microsoft 365 suite) into forces across England/Wales moves policing across the incompatibility barrier. This will interlink forces and provide a single, secure, national operating platform for the sharing of data, documents, and information. In addition, a National Management Centre is evolving to deliver the nationally supported cyber security protection facility for police forces across England/Wales (NEP, 2021). Finally, an Identity and Access Management service is being established, which will help forces securely manage access to the devices used by officers, staff, and the frontline, and speed information access. However, even with this move forward, the HASC observe that the NEP is "woefully unambitious and will not solve the problem" (HASC, 2018, p. 63), so cannot be regarded as the panacea for resolving these issues.

\section{Specialist skills}

Detective Inspector Graham McLaughlin (NPoCC Operations) (G. McLaughlin, personal communication, 29 January 2021) has considered the long-term implications of national coordination. He acknowledges that the evidence of the pandemic supports the case of effective national coordination with regional flexibility. A step being undertaken by NPoCC is the co-location of the Strategic Intelligence and Briefing Team. This unit has a national remit to monitor intelligence and prevailing threats that may require a large-scale or multiple-force response (not CT). It consists of analysts and researchers across the 43 forces brought together (on secondment) in an intel hub. Whilst this seems counter-intuitive to the argument that best IT can enable remote connectivity, this is an example of when physical pooling of national resource together is necessary. Detective Inspector McLaughlin highlighted some changes that further support the case for a national policing structure and may act as a catalyst to move the argument forward. For example, NPoCC has been responsible during the pandemic for ensuring that national specialist skills coverage has been maintained across forces (public order etc.) in line with the Home Office Strategic Policing Requirement (SPR), Part B of which is the National Policing Requirement (NPR). The Home Office are currently reviewing the NPR. The SPR relates to national threats not defined by any force boundaries: terrorism, cyber-crime, public order, civil emergencies, child sexual abuse, and serious and organised crime. The HMICFRS (2017a) effectiveness review found that, generally, forces worked constructively with organisations to develop joint responses, often linked into the statutory Local Resilience Forum (LRF) network. Some forces (Greater Manchester Police were highlighted) had gone much further in creating a Strategic Coordination Centre (SCC) to assist the Strategic Coordination Group (consisting of other blue light and key partners), with an integrated response during times of crisis as outlined in the Greater Manchester COVID-19 Management 
Plan (GMCA, 2020). The National Crime Agency (NCA) (2019, cited in HMICFRS, 2019) estimate there to be more than 350,00o people in the UK involved in serious and organised crime: crime that is particularly complex and painstaking to investigate, requiring officers with specialist skills, or crime that often involves extremely vulnerable people and requires expertise in fields of investigation, such as digital forensics amongst others.

\section{Changing crime methods}

Since the Police Reform Act 2002, HMICFRS have been inspecting police performance in England and Wales with the Home Secretary holding forces to account. In 2015 and 2016, HMICFRS noted that police were falling behind the curve of rapidly changing criminal behaviour - trying to police today's criminality with yesterday's tools, leaving them ill-prepared for the future (HMICFRS, 2017a). HASC (2018) assert that there is strong evidence to suggest that the police are struggling to keep up with increased demands and that in the 20152018 period, despite a $32 \%$ increase in recorded crime, there was a $26 \%$ decrease in charges brought (equating to 153,00o fewer criminals brought to justice). This was coupled with HMICFRS (2017a) reporting that many forces were also struggling to maintain emergency call response time compliance, meaning police were not attending calls from the public when they were needed most. HASC (2018, p. 13) highlight "the wider Crime Survey also found recent steep increases in robbery and theft. If these trends continue, the service risks both a serious decrease in public safety and in confidence in the police and the CPS". Therein lies the problem; criminal behaviour has overtaken the policing model. As Supt Ronnebro illustrated, the pandemic has highlighted the changes in crime patterns and accelerated the need for policing to adapt to keep up. County Lines activity has quietly but effectively moved drug crime from urban into rural areas. The NCA illustrate that gangs are making best use of technology to evade police, and with that success comes the increasing use of violence and exploitation of vulnerable people and children, for example, online grooming of young people to take part in the movement of drugs (NCA, 2017). In an interview on 8th January 2021, Detective Inspector Mark O'Donoghue (Joint International Policing Hub) outlined the importance of work being undertaken in Vietnam with other law enforcement partners to train local officers in Modern Slavery and Human Trafficking investigation and prevention. These are examples of global crimes that need a coordinated response, and which feature in the NPCC Vision 2015. Winsor notes that the current 43 -force structure is no longer fit for purpose. He says, "in too many respects, the lines on the map that delineate force boundaries act as barriers to the exchange of intelligence, to cooperation and to true effectiveness and efficiency" (HMICFRS, 2019, p. 35). In the case of child sexual abuse, Cassandra Harrison (Director of the Centre on Child Sexual Abuse) (2018, cited in HASC, 2018, p. 33) explained that research estimated that $5 \%$ of boys and $15 \%$ of girls will experience some form of abuse as a child and, furthermore, the committee found through hearing witness evidence that across all forces, indecent images of children offences were up $424 \%$ between 2017 and 2018 , with many forces without the capacity or sufficiently trained staff to deal with this increase. Sir Tom Winsor is very clear that, until the structure of policing is modernised, efficiency will be compromised as police forces fail to cope with local, regional, national, and international crime patterns (HMICFRS, 2019).

\section{Scotland's experience}

In considering a national police service, it is useful to look at what happened when the national policing model was implemented elsewhere. Fyfe and Terpstra (2019) have considered the gaps that emerged after the 2013 implementation in Scotland and the Netherlands, between the original reform plan and what was established in practice. Behind the drive for reform sat very similar policing frameworks, in so far as Scotland was operating under the 
Vol. 8, No. 1, 114-130.

tripartite system, whereas in the Netherlands, control over police "administration" (organisation and resources) and "authority" (power to decide what the police should do) lay at more local Mayoral and Public Prosecutor level. Fyfe and Terpstra (2019) outline the arguments for reform in both countries that are very similar to the case being made by Winsor (HMICFRS, 2019). For example, the fragmented nature of regional police systems made efficiency in dealing with cross-border crime difficult, not in small part to incompatible IT systems. The Police and Fire Reform (Scotland) Act 2012 came into law in the midst of a period of austerity under the Westminster Government and, as such, Fyfe and Scott (2013, cited in Fyfe and Terpstra, 2019) note that there was financial incentive in creating a single force - a sizeable $10 \%$ saving without reducing police officer numbers. There was also a requirement to provide more equal access to specialised units across Scotland (something which under the regional system was seen as very uneven and dependent on where you lived). Fyfe and Terpstra further note that, in Scotland, there was also the independence agenda to be taken into consideration, and the creation of "Police Scotland" fulfilled a step forward in signifying Scottish identity (2014, cited in Fyfe and Terpstra, 2019). Similarly, in the Netherlands, Algemene and Rekenkamer note that frustration had developed within the government about the lack of progress made by regional forces to improve collaboration in tackling some of the country's pressing crime needs, highlighted in an inspection report in 2010 (2011, cited in Fyfe and Terpstra, 2019). Terpstra asserts that the Netherlands unification plan for the police was directed at removing fragmentation and lack of cooperation between forces, reducing local government, seen as necessary to reducing the influence of local government individuals, and creating a strategic plan to resolve the long-term problems causing concern within policing, for example, IT (2013, cited in Fife and Terpstra, 2019).

As the implementation took place, many of the challenges met were similar to the concerns heard today about a similar model in England and Wales. For example, Fyfe (2019) notes that the term "Strathclydification" came to represent the sense from within and outside policing that the policing approach of the dominant regional force, Strathclyde, was being adopted for Police Scotland, an approach which had a strong enforcement and performance target theme (2015, cited in Fyfe and Terpstra, 2019). Detective Inspector Graham McLaughlin noted that there was a similar fear of an England and Wales force being dominated by London's Metropolitan Police Service's style of management and policing. During the reform implementation in Scotland, the anticipated savings were not quite as expected, resulting in money having to be saved elsewhere in order to maintain the baseline promise that no police officer numbers would be lost. This meant an impact on assets, such as sale of estate and loss of civilian staff jobs, which, in turn, equated to valuable time taken up on administrative roles previously completed by police staff colleagues and an erosion of public confidence in the police, since officers have less and less of a footprint in the community. Furthermore, the timescales and impact of the enormous change programme on staff and staff morale was significantly under-estimated. In both of the sets of reform plans, local policing and partnership working as an activity was seen as very important, yet was in danger of being undermined by the very plan set to enhance it through a loss of "localness" about the new policing approach.

\section{Conclusion}

In many ways the innovation shown during the pandemic has been the result of clever people re-thinking and re-purposing existing operational activities to meet the changing demands posed by COVID-19. Creating positives from negatives, as in the case of the surplus thawed Pfizer vaccines that were having to be thrown away when people did not attend appointments could they be made available to frontline responders who were already on duty and able to attend vaccination centres quickly at the end of the day without compromising the priority 
system? If they could it would save money and lives. Supt Wheeler confirms that this is something being actively pursued by the Operation Talla (PPE) team. The move towards ever more national coordination in policing, driven by the pandemic, looms large over policing. A single, national police organisation, operating under one unified structure with regional variation to account for the needs of different communities, could put an end to the lack of consistency and variance of interpretation of existing national standards. HMICFRS (2013) define police effectiveness as reducing recorded crime through intelligent, visible policing, as it was in 1829 (Home Office, 2012). In HASC (2018) the Police Superintendent's Association of England and Wales, in calling for a complete review of the policing structure, made the submission that the current force structure is a barrier to achieving reforms and greater efficiencies and effectiveness. In the same report, the Police Federation of England and Wales describe the system as 43 'fiefdoms' (HASC, 2018).

Although the Scotland model found that the expected financial savings of a unified service did not meet original expectations, such a model enables a different view of investment in policing. A less short-term, localised approach, and a longer-term capital investment in such areas as technological capability is considered necessary by Winsor to build a sustainable financial platform for longer term planning (HMICFRS, 2019). The challenge here, again, is national coordination and leadership, to drive through wholesale change programmes. The HASC (2018) and Sir Tom Winsor (2019) conclude in their respective reports that the Home Office must take a much stronger role in driving change forward. In its 2018 report, the National Audit Office describe 21 risks to the financial sustainability of police forces under the existing structure (National Audit Office, 2018). It identifies that the Home Office's "light touch" approach has led to a lack of attention to forces future financial viability. It highlights that there is no common standard for measuring all demands for service and related costs, and therefore no national picture of what force requirements are. Furthermore, it reveals a lack of over-arching Home Office financial strategy for forces, limiting its ability to plan investment and work programmes over the long-term in support of the Policing Vision 2025. The lack of investment strategy also impedes Police and Crime Commissioners in their ability to plan and implement work.

Winsor suggests that the College of Policing should take a greater role in establishing common practices and procedures. He notes that forces are currently largely free to operate in the way they best meet local demands and, whilst this arrangement gives forces considerable flexibility, it can come at a cost (HMICFRS, 2019). For example, different operating procedures between forces can lead to significant inconsistencies, for example National Crime Reporting Standards. Chief Constable Ian Hopkins left his post when HMICFRS identified that 80,00o crimes had gone unreported in April-June 2020 (Halliday, 2020). Instances like this erode police legitimacy. HMICFRS (2017b) outline two principles of policing that support legitimacy. "Procedural justice" (the public believing that they will be treated respectfully and decision-making will be fair) and "organisational justice" (decisions made that affect police officers are made fairly and they themselves feel they are being treated with respect). Inconsistent direction and policy across 43 forces, which results in inconsistent action and further leads to media criticism of officers (Day, 2020 and Grant, 2021), must therefore start to undermine public confidence in police and the legitimacy for the actions they are having to take. The combined effect of lack of financial sustainability impeding forces' ability to invest and keep abreast of accelerating changes in crime methodology and, in so doing, be effective and efficient at reducing and preventing crime, whilst maintaining their protective security obligation can only call into question the public's trust in the police, and therefore their consent to the action being taken by police. The question of police legitimacy remains at the very heart of this debate as the pandemic forces government and police forces to consider, yet again, their position for the future. 
Vol. 8, No. 1, 114-130.

The HMICFRS (2019) State of Policing report highlights the need for a greater integration of public services, and whilst bodies like the ESCWG are striving towards that end, there are challenges elsewhere. Terpstra (2013, cited in Fyfe and Terpstra, 2019) notes of the Netherlands reform plan that it was largely driven by the view in government that regional forces were simply not making sufficient progress or effort in a collaborative policing plan, and this contributed to a radical political re-think on the need for police reform. Winsor sums up the precipice policing in England and Wales appears to be on and for which a single organisation may offer, in part, a bridge: "There is an increasingly pressing need to develop an effective and efficient single system of law enforcement, with clear local, regional and national components" (HMICFRS, 2019, p. 37). The question remains, when will the Home Secretary consider acting on these recommendations?

\section{Note}

${ }^{1}$ Karen Duckworth has 32 years of experience of policing London. As Police Operations Lead at RichmondUpon-Thames Borough, she had responsibility for the review and implementation of policing plans for all events at the Rugby Football Union (RFU) stadium (Twickenham). She worked closely with RFU and other strategic partners to use new legislation reviewing outcomes for training and learning delivery. She performed the role of Silver match commander at RFU events and was key in planning and delivering the local response to the London 2012 Olympic cycling events being held in West London. karen.duckworth@lonpolcol.co.uk

\section{References}

BBC News (2006) Setback for police merger plans. BBC News, 24 February. Available at: http://news.bbc.co.uk/1/hi/uk_politics/4748594.stm [Accessed: 11 February 2021].

Chambers, R. (2020). Lockdown during covid-19: the New Zealand police model of crime prevention and tackling crime/demand changes. [Conference presentation]. The London Policing College 2nd International Police Education Conference - policing in a time of pandemic. [Online conference, 26th October 2020]. Available at: https://1drv.ms/v/ s!Ajj4EO1FLvNUrkeyzuWXP $51 E_{\text {E_woZ? }}=\mathrm{e}=\mathrm{TLP} 4 \mathrm{ls}$.

Crest Advisory (2020) Policing the long Crisis: an appraisal of the police response to Covid19. Available at: https://www.crestadvisory.com/post/policing-the-long-crisis-an-appraisalof-the-police-response-to-covid-19. [Accessed: 15 January 2020].

Day, J. (2020) Britons defy Boris Johnson by flocking to parks despite coronavirus threat. Express Online. 23 March. Available at: https://www.express.co.uk/news/uk/1258836/ london-coronavirus-richmond-park-pictures-greenwich-park-national-trust-news-nhs-latest [Accessed: 17 January 2021].

Emergency Services Collaboration Working Group (2017) Paper 2: National Overview of Collaboration Initiatives. Available at: https://ga.moderngov.co.uk/documents/s9908/ Appendix.pdf [Accessed: 28 January 2021].

Emergency Services Times (2017) Emergency Service Collaboration Working Group calls for response to questionnaire. Available at: https://emergencyservicestimes.com/emer gency-services-collaboration-working-group-calls-response-questionnaire/ [Accessed: 28 January 2021].

Fyfe, N. and Terpstra, J. (2019) Great Expectations? Assessing the creation of national police organisations in Scotland and the Netherlands. Police Science and Management, 
21(2), 101-107. Available at: https://journals.sagepub.com/doi/pdf/10.1177/1461355719842310 [Accessed: o6 February 2021].

Gant, J. (2021) "Police are told to fine COVID-19 rule breakers after just ONE verbal warning as three officers 'arrest a woman for sitting on a bench' and another is surrounded for 'leaving her house more than once”". Mail Online. 12 January. Available at: https://www.dailymail. co.uk/news/article-9130133/Police-told-fine-Covid-rule-breakers-just-ONE-verbal-warning. html [Accessed: 17 January 2021].

GMCA (2020) Greater Manchester covid-19 management plan: how we control outbreaks. Available at: https://greatermanchester-ca.gov.uk/coronavirus/covid-19-management-plan/ [Accessed: 12 February 2021].

Halliday, J. (2020) Patel attacks Burnham as Greater Manchester police chief resigns. The Guardian online. 18 December. Available at: https://www.theguardian.com/uk-news/2020/ $\mathrm{dec} / 18 /$ manchester-police-chief-resigns-after-force-fails-to-log-a-fifth-of-crimes [Accessed: 28 January 2021].

Hewitt, Martin. (2020). Coronavirus crisis 2020 - the national policing response. [Conference presentation]. London Policing College and International Police Education Conference policing in a time of pandemic. [Online conference, 8th December 2020]. Available at: https:// www.youtube.com/watch?v=JqRPa5IofYE

HMIC (2005) Closing the Gap - a review of the "fitness for purpose" of the current structure of policing in England and Wales. Available at: https://www.justiceinspectorates.gov.uk/ hmicfrs/media/closing-the-gap-20050911.pdf [Accessed: 11 February 2021].

HMICFRS (2013) Stop and search powers: are the police using them effectively and fairly? Available at: https://www.justiceinspectorates.gov.uk/hmicfrs/publications/stop-and-searchpowers-20130709/ (Accessed o4 November 2020).

HMICFRS (2014) Policing in austerity - meeting the challenge. [Online]. Available at: https:// www.justiceinspectorates.gov.uk/hmicfrs/wp-content/uploads/policing-in-austerity-meet ing-the-challenge.pdf [Accessed: 20 November 2020].

HMICFRS (2017a) PEEL: Police effectiveness: a national view. Available at: https://www.jus ticeinspectorates.gov.uk/hmicfrs/wp-content/uploads/peel-police-effectiveness-2017-2.pdf (justiceinspectorates.gov.uk) [Accessed: o6 February 2021].

HMICFRS (2017b) PEEL:Police legitimacy 2017: a national overview. Available at: https://www. justiceinspectorates.gov.uk/hmicfrs/wp-content/uploads/peel-police-legitimacy-2017-1.pdf (justiceinspectorates.gov.uk) [Accessed: 03 February 2021].

HMICFRS (2019) State of policing - the annual assessment of policing in England and Wales. Available at: https://www.justiceinspectorates.gov.uk/hmicfrs/wp-content/uploads/stateof-policing-2019.pdf [Accessed: 29 January 2020].

Home Affairs Select Committee (2018) Policing for the future - tenth report of session 2017-2019. Available at: https://publications.parliament.uk/pa/cm201719/cmselect/cmhaff/515/515.pdf [Accessed: 11 February 2021].

Home Office (2012) FOI release - Definition of policing by consent. Available at: https:// www.gov.uk/government/publications/policing-by-consent/definition-of-policing-by-consent [Accessed: 29 November 2020].

London Assembly (2013) Smart policing: how the Metropolitan Police Service can make better use of technology. Available at: https://www.london.gov.uk/sites/default/files/gla_migrate_ 
Vol. 8, No. 1, 114-130.

files_destination/Police\%2otechnology\%2oreport\%2o-\%2oFinal\%2oversion.pdf [Accessed o9 November 2020].

National Audit Office (2018) Financial sustainability of police forces in England and Wales 2018. Available at: https://www.nao.org.uk/wp-content/uploads/2018/og/Financialsustainability-of-police-forces-in-England-and-Wales-2018-Summary.pdf [Accessed: 11 February 2021].

National Enabling Programme (2021) What we do. Available at: https://www.transforma tion.police.uk/what-we-do/identity-access-management [Accessed: 29 January 2021].

NCA (2017) County lines violence, exploitation and drug supply 2017: national briefing report. Available at: https://www.nationalcrimeagency.gov.uk/who-we-are/publications/234-countylines-violen-ce-exploitation-drug-supply-2017/file [Accessed: 31 January 2021].

Neyroud, P. (2021). The changing face of policing. [Seminar presentation]. Birmingham University Jubilee Centre Seminar: The Complexities of Police Ethics in the 21st Century: Is there a role for moral character? [Online seminar, 2oth January 2021]. Available at: https:// www.jubileecentre.ac.uk/

NPCC (2016) Policing Vision 2015. Available at: https://news.npcc.police.uk/releases/policechiefs-and-pccs-set-out-a-vision-for-policing-in-2025 [Accessed: 25 October 2020].

Office for National Statistics (2020) Coronavirus and crime in England and Wales: August 2020. Available online: https://www.ons.gov.uk/peoplepopulationandcommunity/crimean djustice/bulletins/coronavirusandcrimeinenglandandwales/august2020\#trends-in-policerecorded-crime [Accessed: 10 February 2021].

Office for National Statistics (2021) Coronavirus (covid-19). Available at: https://www.ons. gov.uk/peoplepopulationandcommunity/healthandsocialcare/conditionsanddiseases [Accessed: 11 February 2021].

Pollock, A. and Lancaster, J. (2020) Asymptomatic transmission of Covid-19. BMJ, 371, m4851. Available at: https://www.bmj.com/content/bmj/371/bmj.m4851.full.pdf [Accessed: 21 January 2021].

Reiner, R. (200o). The Politics of the Police. 3rd ed. Oxford: Oxford University Press.

Reuters (2020) Criminals using food delivery services to transport drugs during lockdown Interpol. Available at: https://www.reuters.com/article/us-health-coronavirus-interpolidUSKBN22C22D [Accessed: 10 February 2021].

Ronnebro, M-B. (2020). Crime development during the Covid-19 pandemic worldwide. [Conference presentation]. London Policing College 2nd International Police Education Conference - policing in a time of pandemic. [Online conference, 8th December 2020]. Available at: https://www.youtube.com/watch?v=k6zCQfiVAQ8.

Shaw, G. and Zhang, X. (2020) The UK Media Coverage of China's Handling of the Coronavirus Outbreak. Global Media and China, XX, 1-22. Available at: https://journals.sagepub.com/ doi/pdf/10.1177/2059436420980072 [Accessed: 10 February 2021].

Strom (2017) Research on the Impact of Technology on Policing Strategy in the 21st Century, Final Report. Available at: https://www.ojp.gov/pdffiles1/nij/grants/251140.pdf [Assessed: 23 November 2020].

Thaler, R. and Sunstein, C. (2008) Nudge: Improving Decisions About Health, Wealth, and Happiness. New Haven: Yale University Press. 
Twist, Matt. (2020) Policing in a time of pandemic. [Conference presentation]. London Policing College 2nd International Police Education Conference - policing in a time of pandemic. [Online conference, 8th December 2020]. Available at: https://www.youtube.com/ watch?v=2pxbGCuvirk.

Walsh, M. (2020). Policing in a time of pandemic. [Conference presentation]. The London Policing College and International Police Education Conference - policing in a time of pandemic. [Online conference, 26th October 2020]. Available at: https://1drv.ms/v/ s!Ajj4EO1FLvNUrkeyzuWXP $51 E_{\text {E_woZ? }}=\mathrm{TLP}_{4} \mathrm{ls}$.

Williams, S. (2020). Lockdown during covid-19: the New Zealand police model of crime prevention and tackling crime/demand changes. [Conference presentation]. The London Policing College 2nd International Police Education Conference - policing in a time of pandemic. [Online conference, 26th October 2020]. Available at: https://1drv.ms/v/ s!Ajj4EO1FLvNUrkeyzuWXP51E_woZ?e=TLP4ls.

Ye, T. (2020) Innovation and reform under sudden public health events. [Conference presentation]. London Policing College 2nd International Police Education Conference - policing in a time of pandemic. [Online conference, 8th December 2020]. Available at: https://www. youtube.com/watch?v=HTQniVbKykg\&list=PL8VsxSEBffCWS_S7JWJk_Qxd8F92WhZj. 